domestic servant. "Master" means the emp'oyer of any apprentice as hereinbefore defined.

"School Authority" means the School Board exercising jurisdiction in the district in which the place of employment is situated, or any elected body which may take over the powers o such School Board; and in places where there is no School Board, it means the County or Borough Council under the Local Grovernment Act, I888, or the Municipal Corporations Acts.

"Technical Education" is an education in the scientific and artistic principles which govern the ordinary operations in any industry.

"Technical School" me uns a place for tecinical education, whether established and maintained-

(a) By the School Authority, and open to all apprentices;

(b) By voluntary effort, and open to the apprentices of more than one master ;

(c) Or by a master for his own apprentices.

"Inspector" means the Inspector of Factories in whose district the place of employment is situated, or if there be no such inspector, then the School Board Visitor for such district.

(3) The Education Department shall forthwith and from time to time prescribe regulations in conformity with the rules for the time being of the Seience and Art Department, in the subjects in respect of which Parliamentary grants are made by the Science and Art Department, for the formation and instruction of classes of elementary school children who have passed the Fourth Standard, and thereupon the School Authority may form such science and art classes, and provide such instruction accordingly, and earn such grants, and may assign such grants to the teachers of such classes, or may otherwise provide for their remuneration.

(4) Every master shall provide each of his apprentices with technical education at a technical school.

(5) Every apprentice shall devote at least two hours a day, five days in the week, during working hours, to study at a technical school.

(6) The School Authority shall annually in January prescribe the time for such study, having regard to the usual working hours in places of employment in their district, and shall publish a table of the times so prescribed. A printed copy of such table shall be conspicuously exhibited by the master in every such place of employment in such positions for such times and in such type and form as the School Authority shall prescribe.

(7) The School Authority shall have power to establish and maintain such technical schools as may be necessary to accommodate and provide technical education for all apprentices in their district whose masters do not otherwise efficiently provide for the technical education of their apprentices. The master of each apprentice shall pay the prescribed fees for his tuition at such schools.

(8) The technical schools established and maintained by the School Authority may provide technical edusation for persons other than apprentices.

(9) The course of studies at such schools, and fees payable for the same, shall be prescribed from time to time by the School Authority, subject to the sanction of the Education Department.

(ro) The inspector shall inform himself as to the sufficiency of the technical education given to apprentices in his district, and report thereon to the School Auth rity and the Education Department at such times and in such manner as they shall respectively prescribe.

The duties, powers, and penalties relating to the office of inspactor, specified in the Factories and Workshops Act, 1878 , shall be applicable to any inspector under this Act, and to any place of employment within the provisions hereof.

The inspectors shall be paid by the School Authority such remuneration for their services under this Act as the Education Department shall approve.

(II) All offences under this Act shall be prosecuted, and all fines under this Act shall be recovered on summary conviction before a Court of Summary Jurisdiction in manner provided by the Summary Jurisdiction Acts.

The provisions of the Factories and Workshops Act, I878, and the Acts amending the same as to legal proceeding; and appeals, shall be deemed to be incorporated in, and made applicable to, this Act.

The punishment for any offence under this Act shall be a fine not exceeding $£ 5$.

(12) The expenses of carrying this Act into execution shall be defrayed by the School Authority, who shall have power to provide for such expenditure by moneys raised, precepts issued, or rates levied under their powers. Sèparate statements of such expenditure shall be furnish 2 d annually to the Education Department.

\section{ZOOLOGICAL NOTES FROM TORRES} STRAITS.

CAUDAL Respiration in Periophthalmus. - At the Birmingham meeting of the British Association, in I886, Dr. S. J. Hickson pointed out that the species of Periophthalmus which he had observed in the Celebes always rested with its tail immersed in water, although the body was out of the same. I do not know whether any experiments have been made on this fish but I have made a few which tend to show that this remarkable animal largely respires by means of its caudal fin. The experiments were made on specimens obtained from a Mangrove swamp on the Island of Mabuiag (Jervis Islands), and may be summarized as follows:-A specimen totally submerged in the sea was perfectly well and lively after forty-two hours. A second specimen lived a day and a half in a vessel containing just sufficient water to keep the tail-fin submerged, but not enough for respiration by means of the gills. (It is possible that the fish would have lived longer, if the sea-water had been continually renewed.) Fish with the caudal fin coated over with gold size, when put in a vessel of sea-water, only lived, on an average, from twelve to eighteen hours, although they could utilize their gills for respiration; others kept under similar circumstances, but not anointed with gold size, lived a day or two, apparently in perfect healt' 1 . On submitting the caudal fins to the microscope, the circulation of the blood appeared to be exceptionally vigorous. I hope to be able to further test these observations on a future occasion.

The Employment of the Sucker-fish (E.heneis) in Turlle-fishing.-The only two references to the employment of the suckerfish in turtle-fishing which I have by me are those in Dr. Guinther's "Introduction to the Study of Fishes," and the "Narrative of the Voyage of H.M.S. Rattlesnake," by J. Macgillivray. The latter (vol. ii. p. 2I) states that he was informed that the natives of Morulug (Prince of Wales Island), Torres Straits, catch a small species of turtle in the following manner:"A live sucker-fish (Echeneis remora), having previously been secured by a line passed round the tail, is thrown into the water in certain places known to be suitable for the purpose ; the fish while swimming about makes fast by. its sucker to any turtle of this small kind which it may chance to encounter, and both are hauled in together!" Dr. Günther (l.c. p. 46r) throws doubt upon the habitual utilization of the Ech:neis for this purpose. In the Straits there are two periods for turtle-fishing, the one during October and November, which is the pairing season, and when turtle are easily speared owing to their floating on the surface of the water; the other, during the remaining months of the year when the turtle frequent the deeper water and the channels between the reefs. It is then that the sucker-fish-or, as the natives term it, "Gapu,"-is utilized. I have, at present, no means of determining the species of Echeneis common in the Straits. I believe it to be E. naucrata, as the species here attains a greater length than E. remora. When going out turtle-fishing, a Gapu is caught, and the more experienced natives have no great difficulty in procuring one when it is required. A hole is made at the base of the caudal fin by means of a turtlebone, and the end of a very long piece of string is inserted in the hole and made fast. The end of a second, quite short, piece of string, is passed through the mouth and out by the gills. By means of these two strings the fish is retained, while slung over the sides of the canoe, in the water. When a turtle is sighted deep down in the water, the front piece of string is withdrawn, plenty of slack being allowed for the hind string. The Gapu on perceiving the turtle immediately swims towards it, and attaches itself to the reptile's carapace. A man, with a long rope attached to an upper arm, dives into the water and is guided to the turtle by the line fastened to the Gapu's tail. On reaching the turtle, the man gets on its back, and passes his arms behind and below the fore-flappers, and his legs in front and below the hind-flappers. The man is then rapidly drawn up to the surface of the water bearing the turtle with him. On the arrival of the 
diver the Gapu usually shifts its position from the carapace to the plastron of the turtle. At the end of the day's fishing the Gapu is eaten. The natives have a great respect for the Gapu, and firmly believe the fish possesses supernatural powers. For example, when there is something the matter with the bow of the canoe, the Gapu is said to attach itself to the neck or the nuchal plate of the turtle; when the lashings of the outrigger to the thwart poles are insecure, the Gapu is believed not to stick fast to the turtle, but to continually shift its position; if the strengthening ties in the centre of the hold of the canoe are faulty, the Gapu is stated to attach itself to the turtle and then immediately to swim away. More than once I was told, "Gapu savvy all the same as man; I think him half devil." The suckerfish is not used to haul in the large green turtle. I was repeatedly told that it would be pulled off, as the turtle was too heavy. The above information was gathered from several sources, and checked by means of much questioning.

Amphioxus. -A species of Amphioxus, apparently very similar to $A$. lanceolatus, was not uncommon at one spot at Mabuiag, at a depth of from 3 to 4 fathoms. A species of this animal is catalogued as follows by $\mathrm{Mr}$. Krefft, in his list of "Australian Vertebrata, Fossil and Recent": "Branchiostoma lanceolatum. Dredged in Bass's Straits, by H.M.S. Herald, at a depth of from 10 to $\mathbf{2}$ fathoms." I am not aware whether it has been found elsewhere in Australian waters.

Thursday Island, November I2, 1888 .

$$
\text { ALFRED C. HADDON. }
$$

\section{UNIVERSITY AND EDUCATIONAL INTELLIGENCE.}

CAMBRIBGE. - The Sedgwick triennial prize has been awarded to Mr. Alfred Harker, Fellow of St. John's College. The subject of the essay is "The Petrology of the Igneous Rocks associated with the Cambrian (Sedgwick) of Carnarvonshire."

\section{SCIENTIFIC SERIALS,}

IN the number of the Fournal of Botany for December 1888 , Mr. S. Le M. Moore has an interesting article on photolysis in Lemna trisulca, in which he contests some of Stahl's conclusions as to the effect of day and night on the relative positions of the chlorophyll-grains on the cell-walls. The remaining articles, both in this number and in that for January 1889 , are chiefly of interest to geographical or systematic botanists. Messrs. Britten and Boulger's "Biographical Index of British and Irish Botanists" has now advanced as far as the letter G.

IN the Botanical Gazette for November I888, Miss E. L. Gregory completes her account of the development of corkwings on certain trees, the trees described in the present instalment being species of Acer and Liquidambar.

\section{SOCIETIES AND ACADEMIES. LONDON.}

Royal Society, November 22, 1888.-“"Report of Researches on Silicon Compounds and their Derivatives. Part I." By J. Emerson Reynolds, M.D., F.R.S., Professor of Chemistry, University of Dublin.

The present investigation was undertaken some years ago with a view to examine the action of the silicon haloids-but more especially of silicon tetrabromide- on various compounds containing nitrogen, as our knowledge of the relations of silicon and nitrogen is extremely limited.

It was ascertained at an early stage of the inquiry that the bromide of silicon is much superior to the chloride as a reagent with nitrogenized compounds, but since the bromide had apparently not been obtained in any quantity even by its discoverer, Serullas, considerable time had to be devoted to working out a method for the production of a sufficiently large supply of this material. The method adopted is described in the full paper.

In the purification of the crude tetrabromide a new chloro- bromide 1 of silicon was arscovered, which boils at $141^{\circ} \mathrm{C}$. This proved to be the compound $\mathrm{SiClBr}_{3}$, which was required to complete the series of possible chlorobromides of silicon.

The first group of nitrogen compounds subjected to the action of silicon tetrabromide included the primary thiocarbamide or sulphur urea, obtained by the author in 1869 , and the allyl-, phenyl-, and diphenyl-thiocarbamides.

All these are shown to unite with silicon tetrabromide, and afford the highly condensed compounds-

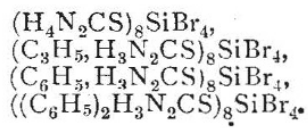

These are more or less vitreous solids, with the exception of the allylic compound, which is a transparent and singularly viscous liquid. All are dissolved and decomposed by water and by alcohol.

The action of alcohol on the compound $\left(\mathrm{H}_{4} \mathrm{~N}_{2} \mathrm{CS}\right)_{8} \mathrm{SiBr}_{4}$ was studied in detail, and it was shown that not only do ethy bromide, thiocyanate, and diethylic silicate result, but that the representatives of two new classes of thiocarbamide derivatives are formed.

The first of these is a beautiful tetrathiocarbamide compound whose formula proved to be-

$$
\left(\mathrm{H}_{5} \mathrm{~N}_{2} \mathrm{CS}\right)_{4} \mathrm{NBr} \text {, }
$$

which may obviously be written-

$$
\left(\mathrm{H}_{4} \mathrm{~N}_{2} \mathrm{CS}\right)_{4} \mathrm{H}_{4} \mathrm{NBr} \text {. }
$$

This body separates from alcohol in fine masses of crystals resembling sea anemones in appearance, which melt at $173^{\circ}$ $174^{\circ}$, and begin to decompose at $178^{\circ}-180^{\circ}$. The synthesis of this substance was effected by heating ammonium bromide with thiocarbamide.

Several homologues of the above tetrathiocarbamidammonium bromide were produced by synthetic methods; some of these contain chlorine or iodine instead of bromine. The following are examples of the compounds found in the course of this part of the investigation:-

$$
\begin{aligned}
& \left(\mathrm{H}_{4} \mathrm{~N}_{2} \mathrm{CS}\right)_{4} \mathrm{H}_{4} \mathrm{NBr}, \\
& \left(\mathrm{H}_{4} \mathrm{~N}_{2} \mathrm{CS}\right)_{4} \mathrm{H}_{4} \mathrm{NCl}, \\
& \left(\mathrm{H}_{4} \mathrm{~N}_{2} \mathrm{CS}\right)_{4} \mathrm{H}_{4} \mathrm{NI}, \\
& \left(\mathrm{H}_{4} \mathrm{~N}_{2} \mathrm{CS}\right)_{4}\left(\mathrm{CH}_{3}\right) \mathrm{H}_{3} \mathrm{NBr}, \\
& \left(\mathrm{H}_{4} \mathrm{~N}_{2} \mathrm{CS}\right)_{4}\left(\mathrm{C}_{2} \mathrm{H}_{5}\right)_{2} \mathrm{H}_{2} \mathrm{NBr}, \\
& \left(\mathrm{H}_{4} \mathrm{~N}_{2} \mathrm{CS}\right)_{4}\left(\mathrm{C}_{2} \mathrm{H}_{5}\right)_{3} \mathrm{HNCl} \text {. }
\end{aligned}
$$

By the action of silver nitrate on the tetrathiocarbamidammonium bromide the crystalline dithiocarbamide compound with silver bromide was obtained-

$$
\left(\mathrm{H}_{4} \mathrm{~N}_{2} \mathrm{CS}\right)_{2} \mathrm{AgBr} \text {. }
$$

This was subsequently produced by the direct union of thiocar bamide with the pure silver haloid. The compound-

$$
\left(\mathrm{H}_{4} \mathrm{~N}_{2} \mathrm{CS}\right)_{2} \mathrm{AgCl}
$$

was also obtained in fine crystals, as were other similar substances.

A trithiocarbamide compound is also formed during the action of ethyl alcohol on $\left(\mathrm{H}_{4} \mathrm{~N}_{2} \mathrm{CS}\right)_{8} \mathrm{SiBr}_{4}$, but it is much more soluble than that which first separates. It is also crystalline, and its analysis and reactions lead to the formula-

$$
\left\langle\mathrm{H}_{5} \mathrm{~N}_{2} \mathrm{CS}\right)_{3} \mathrm{Br}, \mathrm{C}_{2} \mathrm{H}_{5} \mathrm{Br} \text {. }
$$

IIitherto only mono- and di-thiocarbamide derivatives have been known, but the results above stated in outline prove that tri- and tetra-thiocarbamide compounds are formed in presence of silicon tetrabromide and certain other agents, which latter form addition products with the condensed amide.

So far, cases were only dealt with in which silicon tetrabromide combined with nitrogenized groups without loss of its halogen. The next stage of the inquiry involved the investigation of certain interactions in which the tetrabromide loses $a / l$ its halogen. One of the chief results obtained in that direction forms the subject of a separate communication I The chlorine required for the production of this compound was derived
from the crude bromine (which always con'ains chloride of bromine) used in preparing the tetrabromide. 